\title{
ЛИТЕРАТУРА КАК МИФ И ГИПЕРТЕКСТ \\ В БЕСКОНЕЧНОМ ТУПИКЕ ДМИТРИЯ ГАЛКОВСКОГО \\ (К РЕКОНСТРУКЦИИ ИСТОРИОСОФСКОЙ МОДЕЛИ)
}

\author{
LITERATURE AS MYTH AND HYPERTEXT \\ IN THE INFINITE DEADLOCK BY DMITRY GALKOVSKY \\ (TOWARDS A RECONSTRUCTION OF THE HISTORIOSOPHICAL MODEL)
}

\author{
ROMAN SZUBIN
}

\begin{abstract}
This article is devoted to reconstruction of the historiosophical concept in Dmitry Galkovsky's novel The Infinite Deadlock (Бесконечный тупик). The author pays particular attention to the criteria of historiosophy: mythologism, ambivalence of consciousness, hesychast tradition, eidetic language, a universal man (absolute personality). He highlights the demythological factor in Galkovsky's creative work, its cultural and national nihilism. The author analyzes the image of the main character's identity, who is capable of identifying himself, who is humiliated or ingenious. In passing, the author considers the idea of common history in which the eras which dialectically deny each other's coexistence.
\end{abstract}

Roman Szubin, Uniwersytet im. Adama Mickiewicza w Poznaniu, Poznań - Polska, szubin@gmail.com

Судьба книги писателя, философа и публициста Дмитрия Галковского Бесконечный тупик (далее - БТ) удивительна. Написанный в 1988 году, в зените горбачевской перестройки и гласности, роман БТ подвергся травле и, методично бойкотированный издательствами, был полностью опубликован только в 1997 году на пожертвования друзей. Критика посыпалась со всех сторон: молодого автора обвиняли в антисемитизме и русофобии, графомании и невежестве, плагиате и порнографии. В конце 90-х возникла мода на Галковского в науке: его произведение попало во все учебники по современной литературе, изучалось как крупное явление постсовременности и постмодернизма. Небольшая же часть филологов склонна была рассматривать БТ в „дискурсе национального самосознания" 1 .

${ }^{1}$ С. О р о б и й, „Бесконечный тупик” Дмитрия Галковского: структура, идеология, контекст, Благовещенск 2010, с. 10-11. 
Выпускник философского факультета МГУ Дмитрий Евгеньевич Галковский (1960 г. р.) смог творчески реализоваться не в научной академической или в литературной среде, а как „свободный художник” и блогер в Интернете. Одиночество - неизбывная тема его писательства, интеллектуальной жизни, поэтому неслучайно в БТ в качестве „личностного начала" выбран герой с фамилией Одиноков. Можно считать исключением (а исключение также фактор одиночества), что среди гуманитариев столь высокого уровня он единственный, кто всерьез увлекся Интернетом и компьютерными играми. Заметим, что фрагментарная структура гипертекста БТ на несколько лет предвосхищает массовое распространение Всемирной Сети. Д. Галковский - автор философии геймера (Движение утят) и оригинальной концепции истории.

Форма. Своей провокационностью и адогматическим пафосом напоминая Апофеоз беспочвенности (1905) философа-экзистенциалиста Льва Шестова, Бесконечный тупик подражает и форме этого сочинения: афористической, фрагментарной, не имеющей линейной наррации. Жанровая сложность романа, безусловно, связана с тем, что роман БТ не описательный, а метанарративный, это метароман, который часто определяют как филологический роман, философский роман, роман-меннипея. Основную массу текста занимает обширная, более чем на 1000 страниц, разветвленная сеть цитат и авторских комментариев и примечаний к „основному тексту” и к другим комментариям.

В третьем издании, 2008 года, роман представлен наиболее полно и обнаруживает древообразную структуру, отображенную на форзаце книги. Развивая заложенную в тексте метафору дерева (ср. фразу „мысли ветвятся и растекаются по древу"), мы можем описать структуру романа следующим образом: „корнем” является ранняя работа Закругленныи мир (1983-1984), "стволом", или основным текстом, - статья Бесконечный тупик (1984-1985), „ветвями” - 949 комментариев к основному тексту Примечания $\kappa$ „Бесконечному тупику” (1988), „плодами" - рецензии и письма, внесенные в роман по примеру Владимира Набокова. Некоторые из них мистифицированы (например, статья профессора Дитриха фон Хальковски, в имени которого угадывается анаграмма на имя Дмитрий Галковский).

Гипертекстовой характер романа выполняет деструктивно-конструктивную функцию: разрывая линейную наррацию прозы, комментарии взаимодействуют друг с другом как рифмы, дополняя друг друга, соединяя на новом смысловом уровне разорванные края - здесь как раз подходит первичное значение textus 'ткань'. Этим самым создается корреляция формы романа с „круглотой” русского мышления, с „закругленностью” русского самосознания. Книга репрезентирует мышление, становясь им, то есть не описывает бытие, а "бытийствует" 
в русском понимании этого слова 2 . Галковский через своего героя Одинокова пытается прорвать замкнутую линию русского мышления и „лживого" русского языка, представляемого в виде виниловой пластинки с ее витками-дорожками $(5 T, 39)^{3}$. При этом сам он является частью этого круга, а фрагменты романа и есть каждый оборот иглы по пластинке. Чтобы перейти на другой виток, фрагмент должен быть прерван, а не окончен. Но напряженная попытка выйти из себя, за пределы своего мышления оканчивается стремлением к целостности и фундированием самого себя в „круглом” русском мышлении, о чем свидетельствует само название. По словам псевдорецензента БТ Семена Шапкина, автор „накачал огромное силовое поле, магическим кругом защищающее все порождения его фантазии, но внутри бесконечной кругкой ограды...”, растворяясь в „Великом Одиноком океане, бесконечном тупике последнего молчания" (БТ, 1062).

В дальнейшем мы сосредоточимся на проблеме выделения критериев историософичности и символов историософского измерения романа (круг, молчание, тупик).

Демифологический пафос романа. Написанный в период гласности и повсеместного развенчания „идеалов" и „идолов”, роман Галковского представляет собой острый памфлет против традиционного, канонического, школьного подхода к русской литературе. Критика Галковского нацелена в русский литературоцентризм, в силу чего литература выполняет функции религии и философии. Симптоматична ситуация, когда философия зарождается в литературе, в искусстве (Ф. Достоевский, В. Набоков, А. Платонов), философы становятся священниками (о. П. Флоренский, о. С. Булгаков, о. В. Зеньковский, о. Георгий Флоровский), монахами (А. Лосев), писателями (Б. Пастернак) и публицистами (В. Белинский, В. Розанов), а западная философия трансформируется в христианизированную историософию (П. Чаадаев), русскую религиозную философию (Н. Бердяев и др.), софиологию (В. Соловьев), осуществившую своеобразный „синтез отвлеченных начал” и ставшую, по выражению Бориса Гройса, „философски сформулированной анти-философией" 4 .

По замыслу автора Бесконечный тупик - роман антиинтеллигентский. Обвинению прежде всего подвергается мифотворческая тенденция русской интеллигенции, которая во главу угла своего самосозна-

2 М. Э п ш т е й н, Слово и молчание: метафизика русской литературы, Москва 2006, с. 183.

3 Д. Г а л к о в с к и й, Бесконечный тупик: $b 2$ кн., Издательство Дмитрия Галковского, Москва 2008. Здесь и далее - ссылки на это издание приводятся в тексте статьи с указанием названия $5 T$, номера тома и номера страницы.

4 Б. Г р о й с, Поиск русской идентичности, „Вопросы философии” 1992, № 9, с. 52. 
ния поставила искусство и „самый лживый вид искусства” - литературу. Примером такого мифотворчества может служить История русской общественной мысли (1906) Иванова-Разумника, в которой история России проецируется на историю литературы, в силу чего исторические процессы были восприняты в качестве борьбы светлых и темных сил. Согласно логике мифотворчества революция интерпретируется как победа светлых сил над темными, положительных героев-революционеров над мещанством. Эту „наивную” интерпретацию Галковский дополняет более сложным „конспирологическим мифом” всемирной революции, импортированным масонством и зародившимся в умах русских мыслителей-космистов: К. Леонтьева, Н. Федорова, К. Циолковского, чьи идеи по горькой иронии истории реализовались в создании ГУЛАГа, „лагерно-тюремной Индии", если под последней понимать штрафной барак и его жителей 5 . В этом подсознательном для русской ментальности мифе происходит незаметное „смещение понятий добра и зла, фундаментальных категорий духовного мира", выявленное В. Набоковым. По прочтении романа Приглашение на казнь Галковский констатирует: „Коммунизм - это и есть такое смещение, сдвиг элементарных понятий. Вся русская история с 1917 по 1937 год есть развертывание и реализация этого смещения" $(Б T, 1106)$.

Амбивалентность русского мышления. Пафос нигилизма Галковского пронизывает рефлексию над русским мышлением и русским языком: русский язык объявляется „лживым", русское мышление - „двойственным", „ккруглым", то есть самодостаточным и мифологическим. Русский язык „принципиально нефилософский язык. Русский язык мним" (БТ, 1103). Архетипом русского писателя является „деревенский враль" (БТ, 910), типологически связанный с юродивым, не отстраненный софист, а „враль от Бога”. А русская литература культивирует так называемые „заглушки” для интеллигенции, некритически воспринятые мифологемы.

Однако критикуя амбивалентность, Галковский в зоне той же амбивалентности формирует свое видение русского самосознания. Так, в силу упомянутой двойственности подлинным русским философом объявляется Василий Розанов (ему посвящена основная статья - прототекст Бесконечный тупик), публицист крайне противоречивых взглядов, но вписывающийся в структуру амбивалентной русской личности. В качестве правдивого русского писателя выбирается Владимир Набоков, в заслуги которому вменяется тотальный нигилизм к русским классикам и метафизический разрыв с русской классической, софийной, соборной культурой. Набоков „не „революционер”, а реакционер. [...] В Набокове русская культура остыла, окаменела" $(Б T, 1147)$.

5 Ж. Р о с с и, Справочник по ГУЛАГу: в 2-х частях, ч. 1, Москва 1991, с. 138. 
Автор не скрывает своего увлечения Набоковым, самость Набокова адекватна настроениям Одинокова-Галковского.

Исихастский сюжет и эйдетический язык. В. Розанов, В. Набоков, а также Ф. Достоевский выражают так называемый „исихастский характер русской словесности” (БТ, 1139), „русский талант высокого молчания - безмолвствования" (БТ, 228), ориентированный в своих истоках на исихазм (от греч. спокойствие, уединение) - аскетическую практику „умно-сердечной молитвы”, возникшую в византийском Православии в XIV веке и разработанную Григорием Паламой. Главной чертой этой практики является безмолвное созерцание божественных энергий (обо́жение), исихастов называли „священно-безмолствующими”.

Тема молчания русской культуры, безмолвия русского человека переосмысливается Галковским в пользу русской словесности: „«Молчание - золото» - самая литературная пословица" (БТ, 1108), и далее: „из Руси молчаливой возникла великая русская литература. Писаревы же и Чернышевские - из пьяной болтовни" (БТ, 1109). К молчанию сводится бесконечное говорение автора Бесконечного тупика.

Проблема молчания и исихазма у Галковского вводит нас в круг тем, связанных с основами русской культуры, с ее „духовностью”, в которой можно выделить парадигму двуголосия, непрямого говорения, эйдетического языка (от эйдос - вид, образ), софийного мыиления. Первые две концепции связаны с именем Михаила Бахтина, третья - с Алексеем Лосевым и Л. Гоготошвили, четвертая - с направлением русской философии первой трети XX века - софиологией. В этих концепциях проявляется доминирование означающего над означаемым, мифа над логосом, как над что, имяславческого тезиса „имя есть вещъь над антитезисом "вещь не есть имя", сопровождаемое „погашением акта именования в пользу неименующей символической референции, [...] тезисом о принципиальной „непрямоте” смысла на естественном языке”6. Модус непрямого говорения, когда родной язык изображается как иностранный ${ }^{7}$ (или лживый у Галковского, эйдетический у Гоготошвили), обеспечивает автору БТ положение вненаходимости, дистанцирования от „заглушек” интеллигенции, а сам предмет изображения - русский язык в устах Ленина, сталинского прокурора Вышинского, революционеров, некоторых писателей и т. Д. - начинает отражать сознание говорящего, разоблачая его. Или, если быть ближе к стилистике романа, язык становится вариантом оруэлловской уткоречи ${ }^{8}$ - речи, произ-

6 Л.А. Г о г о т о ш в и л и, Непрямое говорение, Москва 2006, с. 418.

7 М. Б а х т и н, Собрание сочинений, т. 3, Москва 2012, с. 171, 551.

8 Напомним, что Д. Галковский - составитель антологии советской поэзии Уткоречь (Псков 2002), собранной из произведений второстепенных поэтов, моделирующих эсхатологическую модель - матрицу русского самосознания. 
водимой гортанью, независимо от мозга: „говорить так, как крякает утка" (БТ, 335).

В случае с концепцией эйдетического языка стоит задаться вопросом: кто есть субъект такого языка, кто говорит на нем? Очевидно, что это не может быть частная личность, но такая, которая является „квинтэссенцией национальной идеи", а это личность собирательная, всечеловеческая. Ответ отсылает нас к проблеме личности в Бесконечном мупике.

Проблема личности как всечеловека для героя в Бесконечном myпике является едва ли не самой жизненной. И эта проблема также погружена в зону амбивалентной интерпретации, в которой личность (индивид) приобретает черты сверхличности, надындивидуальной личности, а безличные формы (коллективность, народ, национальное самосознание) индивидуализируются. Очевидно, что в русском самосознании есть предпосылки появления личности софийного типа, наподобие „брата всех людей” - всечеловека Пушкина в Пушкинской речи Ф. Достоевского. Как вне Софии, Премудрости Божьей, не может быть ничего, так и вне всечеловека не может существовать другой, частной личности. Такого типа личность - продукт русской философии. В ней можно найти такие образования, как „всечеловеческий организм” В. Соловьева, „симфоническая личность” Л. Карсавина, „мирочеловек” С. Булгакова, „многочеловеческая личность” Н. Трубецкого, „абсолютная личность” Г. Шпета и А. Лосева, „Весьчеловек” М. Пришвина. Даже в своем герменевтическом описании русского сознания Вардан Айрапетян внедряет конструкт „мировой человек”, созданный по принщипу „если никто, то все как один” на основе поговорки „Мир - велик человек"9. Но и в мировой мысли встречается антропоморфный Абсолют: всемирный человек (homme universel) Блеза Паскаля, универсальное mело (universal human body) Нортропа Фрая, Единыи-единственный человек Ойгена Розенштока-Хюсси.

На протяжении всего романа герой окружен примерами и образцами личностей, приобретающих „нечто циклопическое”, сверхличностное. В истории - это культ личности (Сталин), вождизм (от Ленина до Горбачева), апофеоз сильного человека (стахановец); в семье - отец Одинокова, любимый, но слабый человек, хотя по-своему сильная личность; в философии - всечеловек Достоевского, Богочеловек Соловьева; в литературе - положительный герой как таковой, герой-революционер и положительный образ писателя-интеллигента; в религии - Бог-личность и олицетворенный черт, антихрист. Из этого круc. 124 .

9 В. А й р а п е т я н, Толкуя слово. Опыт герменевтики по-русски, Москва 2011, 
га выпадает личность западного образца, секуляризованный человек постренессансного типа, познавший свободу воли (Пришвин). Наоборот, понятные и доступные Западу личности Достоевского, Розанова и Набокова в прозе Галковского становятся мифологическими мета-личностями, личностями-вселенными, вбирающими в себя компонент всечеловека, безличия. Одиноков среди этих личностей раздавлен, он не личность даже, а находится в убывающей прогрессии (признается в слабости, в суицидальных наклонностях), между единицей и нулем. Он мечтает стать „абсолютным нулем” - „всё-таки нечто циклопическое" (БТ, 105).

Положение героя Одинокова между нулем и циклопом, между частной личностью и личностью-вселенной, с одной стороны, предельно униженной, а с другой - стремящейся к гениальности, концептуализируется цитатой из Дж. Оруэлла:

Произошло раздвоение. ... Раздвоение-двоемыслие это высший тип мышления члена ангсоцевского общества. При этом человек сохраняет преимущества индивидуальной избирательной реакции на действительность, и одновременно всё же не является личностью (БТ, 76).

Возможно, это один из близких ответов на вопрос об абсолютной личности Одинокова: быть не личностью, но всечеловеком (над личностью) и обладать индивидуальными реакциями.

Метамифология. Очевидно, что демифологизация русского мифа, мифа Соловьева, Толстого, Чехова, Ленина и др. связана с попытками установить новый миф или, словами героя Одинокова, метамифологию (иначе - „вторичную интеллектуализацию”).

Ведь только человек, уверенный в собственной гениальности, может взяться за создание метамифологии (то есть мифологии, в которой потенциально возможно существование самосознания) породившей его цивилизации. Я, Одиноков, должен выступить в виде квинтэссенции национальной идеи, выразить её с максимальной интенсивностью и ясностью. [...] Вобрать эту априорную установку внутрь постепенно распадающегося повествования, сделать её анализ одной из форм этого распада $(Б Т, 228)$.

Неслучайно Сергей Оробий считает эту реплику ключевой в романе. Описывая „противоречие между Словом отца и Молчанием матери", исследователь полагает, что только личность способна демифологизировать реальность. Однако „в условиях постмифологического сознания, то есть сознания современного человека, последовательная реконструкция своего хода мышления и оказывается единственным способом создания мифа"10. Заметим: исследователь здесь признает безуспеш-

10 С. О р о б и й, указ. соч., с. 128-129. 
ность попытки Галковского выбраться из-под власти эйдетического языка и избавиться от доминирования мифа над мышлением.

Реконструкция историософской модели. Мотив „проспективного анамнезиса" (припоминания будущего, того, чего нет) типичен для восточно-христианской историософии и связан с „особой темпоральной логикой, предполагающей, что пребывание во времени, которое оставили позади себя другие [т. е. отставание в истории - Р.Ш.], открывает возможность для сверхкомпенсации - для обгона соперников, участвующих в диахроническом состязании, в борьбе за власть над историей"11.

Для Галковского в этой связи главным становится вопрос: русская история -это свершение того, что невозможно, но о чем уже помыслено. Вадим Руднев на этом основании писал, что в понимании Галковского русская литература обладала „креативностью (все сказанное превращается в действительность); револютативностью, то есть оборотничеством (все сказанное превращается в действительность, но в наиболее искаженном, нелепом и неузнаваемом виде); провокативностью (склонностью к издевательству, глумлению, юродству)"12.

Если действительность - реализация слова, то вслед за В. Розановым Галковский считает, что русская история - это реализация, разворачивание мифа.

Розанов сказал, что „идеи сильнее царств”. Поэтому он предвидел... развертку в реальность мифологии русской интелиигенции, с одной стороны, и мифологии русского еврейства - с другой $(Б Т, 1134)$.

Для Галковского нет разрыва между дореволюционной и пореволюционной эпохой: вторая разворачивается из первой, реализуя идеи и утопии великих мечтателей. Так достигается сосуществование эпох и этапов, диалектически отменяющих друг друга. Прошлое постоянно мистифицируется; зримым примером такой мистификации может служить воплощение идеи единой истории в кинофильме Карена Шахназарова Город Зеро (1988), а также - в наше время - во время торжественного открытия Зимней Олимпиады в Сочи в 2014 году. Даже сталинский период истории представляется как необходимая „расплата" за революцию и расплата с революцией. Однако даже расплата не уберегает интеллигенцию от мифотворчества в период ее геноцида. Мифотворчеством занимается советская идеология, беспощадная к иде-

11 И. С м и р н о в, Последние-первые и другие работы о русской культуре, Санкт-Петербург 2013, с. 8-9.

12 В. Р у д н е в, Философия русского литературного языка $b$ „Бесконечном тупике" Д.Е. Галковского, „Логос” 1993, № 4, с. 72. 
ализму и утопизму предшествующего периода. Мифы диалектического материализма в Истории ВКП(б) - Священной истории большевистской партии, как показывает Михал Гловиньски, „повествуют о формировании некоего мирового порядка, в котором фактор прогресса, упорядоченности, идеологической правоты берет верх - над силами зла и над хаосом, предшествовавшим зарождению и триумфу нового идеала" 13 . Таким образом советская история доводит до крайности мифы софийного мышления, односторонне воспринятые утопические и эсхатологические представлений русских мыслителей, а СССР - это логическое продолжение славянофильского историософского мифа. Причем Галковский достраивает эсхатологические представления славянофилов эсхатологией советского человека:

Во мне, как и в любом русском, проигрывается русская история. И в генофонде заложена библейская идея конца мира и т. д. Я живу в этом апокалиптическом мире - масоны, антихрист-Ленин, - потому что этот мир живёт во мне $(Б T, 80)$.

Вот почему Советский Союз дополняет русский миф, а постсоветский человек живет этим мифом.

„Советский Союз” был выдуман и затем скрупулёзно воссоздан наяву. Oн дополняет русское сознание, позволяет ему чувствовать себя уютно. Всё становится таким ясным, понятным $(Б T, 80)$.

История разворачивается из многослойного мифа-луковицы и затем прилагается к сознанию. Округло-острая, „ироничная и подслеповатая" луковица у Галковского - красноречивый символ русской „молчаливой цивилизации" (БТ, 1161).

Поэтому собственно мифическая составляющая русской истории сакрализуется и превращается в религиозную тайну. Принятие тайны - это не интерпретация мифа и его растворение в истории, а соединение „субъекта и объекта веры” $(5 T, 166)$. Русский человек с „нашим юродством", „великой литературой”, по мнению Галковского, философ, но тайна русской философии в том, что, в отличие от Запада, „вырваться можно только молчанием”, что русская история разрешается забвением:

Сила русского забвения так велика, что мы забыли и само забвение, забыли социализм, который, всеми брошенный, как-то тихо и незаметно кончается. Это типично русский конец идеи (БТ, 1112).

${ }^{13}$ М. Г л о в и н ь с к и й, „Не пускать прошлого на самотек”: „Краткий курс ВКП(б)” как мифическое сказание, „Новое литературное обозрение” 1996, № 22, [в:] электронный ресурс: <http://www.situation.ru/app/j_art_776.htm> (26.11.2016). 
Заключение. Таким образом, несмотря на внешнюю деструктивную направленность романа Бесконечный тупик, его древообразная фрагментарная конструкция становится утверждением единства и целостности. Критика русской философии европейского образца превращается в презентацию самобытной русской философии. Важной частью последней является „метамифология” субъекта, в котором угадывается сверхчеловеческая личность, имеющая своим идеалом личность воплощенного Бога, а мифологическим архетипом образ Первочеловека. В этих пределах и формируется русское понимание личности. В основе романа прощупывается настойчивый поиск исихастской традиции, за которой скрыто понимание личности как единого образа мира. А на поверхности романа проявляется стремление преодолеть советскую мифическую установку на литературоцентризм, воспринимаемый автором как аннигиляция личностного начала и служба литературы тоталитарному государству.

\section{Библиография}

А й р а п е т я н В., Толкуя слово. Опыт герменевтики по-русски, Москва 2011.

Б а х т и н М., Собрание сочинений, т. 3, Москва 2012.

Г а л к о в с к и й Д., Бесконечный тупик: 82 кн., Издательство Дмитрия Галковского, Москва 2008.

Г л о в и н ь с к и й М., „Не пускать прошлого на самотек”: „Краткий курс ВКП(б)” как мифическое сказание, „Новое литературное обозрение” 1996, № 22, [в:] электронный ресурс: <http://www.situation.ru/app/j_art_776.htm> (26.11.2016).

Г о г о т о ш в и л и Л.А., Непрямое говорение, Москва 2006.

Г р о й с Б., Поиск русской идентичности, „Вопросы философии” 1992, № 9, с. 52.

О р о б и й С., „Бесконечный тупик” Дмитрия Галковского: структура, идеология, контекст, Благовещенск 2010.

Р о с с и Ж., Справочник по ГУЛАГу: в 2-х частях, ч. 1, Москва 1991.

Р у д н е в В., Философия русского митературного языка $b$ „Бесконечном тупике” Д.Е. Галковского, „Логос" 1993, № 4.

С м и р н о в И., Последние-первые и другие работы о русской культуре, Санкт-Петербург 2013.

Э п ш т ей н М., Слово и молчание: метафизика русской литературы, Москва 2006. 